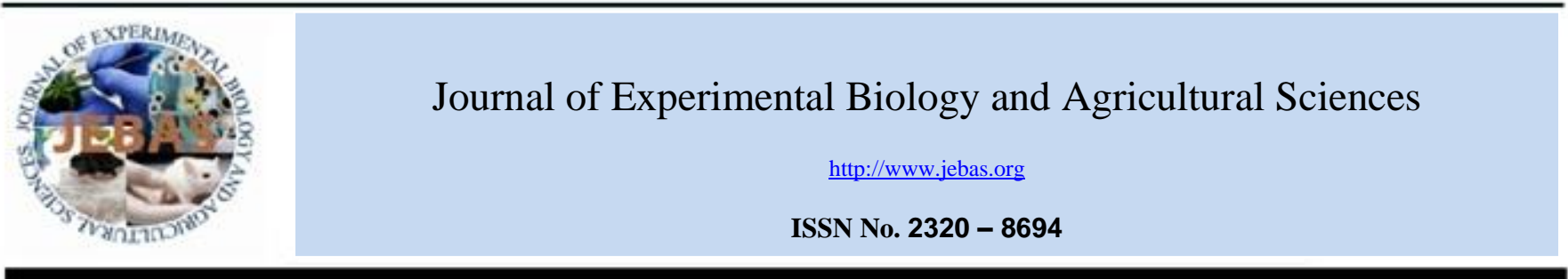

\title{
PLANT GROWTH POTENTIAL OF SALT TOLERANT ENDOPHYTE Pseudomonas Sihuiensis ISOLATED FROM CHICKPEA
}

\author{
Navneet Joshi ${ }^{1, *}$, Laxmi Choudhary ${ }^{1}$, Kanti Prakash Sharma ${ }^{1}$, Hafiz M.N. Iqbal ${ }^{2, *}$ \\ ${ }^{1}$ Department of Biosciences, Mody University of Science and Technology, Lakshmangarh, Sikar, Rajasthan, India \\ ${ }^{2}$ Tecnologico de Monterrey, School of Engineering and Sciences, Monterrey 64849, Mexico
}

Received - January 01, 2021; Revision - April 09, 2021; Accepted - April 20, 2021

Available Online - April 25, 2021

DOI: http://dx.doi.org/10.18006/2021.9(2).231.238

\section{KEYWORDS \\ Endophyte \\ Semi-arid zone \\ Salt stress \\ Exopolysaccaharide \\ Biofertilizer \\ Agricultural use}

\begin{abstract}
Bacterial endosymbionts are well characterized for plant growth promotion. In this study, the root, nodules, and stem of the Cicer arietinum crop planted in a semi-arid zone were used as a source to isolate potential plant growth bacteria. The ability to grow under salt stress was determined, and the potential isolate was screened for plant growth promotion traits. The selected isolate was identified by the $16 \mathrm{~S} r \mathrm{DNA}$ method. Pot trials were conducted to know the ability of the isolate to promote plant growth in-vivo. Among various isolates obtained, a bacterial isolate obtained from root showed the ability to grow in the presence of $10 \%$ Sodium fluoride $(\mathrm{NaF})$. The isolate produced Indole Acetic acid in an amount of $72 \mathrm{mg}$ per liter in production medium. The bacteria solubilized phosphate and produce exopolysaccharide (2.12 g per liter). The isolate was identified as Pseudomonas sihuiensis. The result of pot trials reveals that the endophyte promotes plant growth under stress conditions and may be used as a bio-fertilizer.
\end{abstract}

* Corresponding author

E-mail: navybiotech@gmail.com (Navneet Joshi); hafiz.iqbal@tec.mx (H.M.N. Iqbal)

Peer review under responsibility of Journal of Experimental Biology and Agricultural Sciences.

Production and Hosting by Horizon Publisher India [HPI] (http://www.horizonpublisherindia.in/).

All rights reserved.
All the articles published by Journal of Experimental Biology and Agricultural Sciences are licensed under a Creative Commons Attribution-NonCommercial 4.0 International License Based on a work at www.jebas.org.

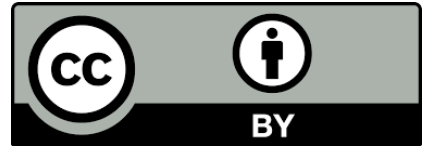




\section{Introduction}

Drought, high as well as low temperature, and soil salinity are among the main abiotic constraints limiting crop productivity (Sabagn et al., 2019). Salt stress disturbs the plant's carbon and nitrogen assimilation process and decreases plant productivity (Schirawski \& Perlin, 2018). Several researchers explored the possibility to ameliorate salt stress by plant growth-promoting rhizobacteria.

The interest in endophytic bacteria has been increased nowadays as they harbor the host plant's internal tissues and represent an opportunity to contact the plant's cells and, therefore, to more readily exert a direct beneficial effect (Santoyo et al., 2016). These bacteria improve plant productivity by inducing the production of plant growth regulators (osmoprotectants, exopolysaccharides, and the modulation of plant physiochemical constituents (De Vuyst et al., 1998 \& El-Akhdar et al., 2020). Previous literature revealed that the association of fungal community or endophytic bacteria with the root of crop plants helps them to perform under stress conditions (Ghaffari et al., 2016; Hashem et al., 2016; Li et al., 2017 \& Zhang et al., 2019).

India produces a maximum portion of the world's total annual production of chickpea (Mansotra et al., 2015). The growth of chickpea is considered very sensitive to salinity (Khan et al., 2017). Very few reports suggest the use of endosymbionts to ease plant stress concerning $\mathrm{NaCl}$ (Ahmad et al., 2015). Still, there is no research about chickpea plant tolerance towards the $\mathrm{NaF}$ (Sodium Fluoride) toxicity. Recently an endophytic Bacillus subtilis was isolated (Flowers et al., 2010 \& AbdAllah et al., 2017), which improves the tolerance of chickpea plants against $\mathrm{NaCl}$ caused salt stress by inducing phytochemical-based plant defense. Thus, considering the need for more information to alleviate salt stress given the economic importance of the Chickpea plant, the present study is planned to isolate an endosymbiont that can tolerate $\mathrm{Na}^{+}$ and $\mathrm{F}^{-}$toxicity and promote plant growth.

\section{Materials and Methods}

\subsection{Isolation of bacterial endosymbionts from $C$. arietinum}

Endosymbionts were isolated using the standard methodology as suggested (Egamberdieva et al. 2017). Healthy plants were collected from Lakshmangarh, District-Sikar, Rajasthan, India $\left(27.82^{\circ} \mathrm{N} 75.02^{\circ} \mathrm{E}\right)$ in polythene zip-bags and were immediately brought into the laboratory. The plants were thoroughly washed with tap water and finally rinsed with distilled water. Nodules were separated and stem and root were cut to obtain $1 \mathrm{~cm}$ pieces under aseptic conditions. Root, stem pieces, and nodules were surfacesterilized, followed by Tween 80 treatment for 10 minutes. Above obtained samples were washed with distilled water and incubated with sodium hypochlorite ( $1 \%$ available chlorine) for 10 minutes, followed by $70 \%$ ethanol treatment for 1 minute. The samples were finally washed with sterilized distilled water. This wash was used as a source to isolate surface bacteria associated with plant samples. Plant samples were macerated in Phosphate buffer saline (100 mM, pH 7.0) in the presence of an ice jacket. Each macerated sample was serially diluted and was spread plated into a nutrient agar plate of $\mathrm{pH}$ 7.0. The plates were incubated at $30^{\circ} \mathrm{C}$ along with control (without inoculum) for 5 days. Morphologically distinct colonies were selected, purified, and used for further studies.

\subsubsection{Screening of bacterial isolates for salt tolerance}

The isolates obtained above were checked for their tolerance towards salt stress. Filter sterilized $\mathrm{NaF}$ was added at a concentration of $10 \%$ (g) i. e. $10 \mathrm{~g}$ in $100 \mathrm{ml}$ of the nutrient broth and nutrient agar medium after autoclaving. A loop full of bacterial culture was inoculated into the nutrient broth and incubated at $30{ }^{\circ} \mathrm{C}$ at $150 \mathrm{rpm}$ for 24 hours. The growth was spread plated onto nutrient agar of $\mathrm{pH} 7$ supplemented with $\mathrm{NaF}(10 \mathrm{~g} \%)$. The agar plates were incubated overnight at $30{ }^{\circ} \mathrm{C}$, and growth was determined in terms of colony-forming units (CFU). A Petri plate without inoculum served as control.

\subsubsection{Screening of plant growth potential in isolate}

All isolates were checked for various plant growth-promoting activities as phosphate solubilization, Indole-3-acetic acid production, EPS production.

\subsection{Phosphate solubilization}

The bacterial isolates were screened for their ability to enhance plant growth concerning phosphate solubilization and IAA production by following the method suggested (Brígido et al., 2019). The isolates were inoculated on Pikovskaya agar medium (Glucose $10 \mathrm{~g}$, Calcium phosphate $5 \mathrm{~g}$, Ammonium sulfate $0.5 \mathrm{~g}$, Sodium chloride $0.2 \mathrm{~g}$, Magnesium sulfate $0.1 \mathrm{~g}$, Potassium chloride $0.2 \mathrm{~g}$, Ferrous sulfate $0.002 \mathrm{~g}$, Yeast extract $0.5 \mathrm{~g}$, Manganese sulfate $0.002 \mathrm{~g}$, agar $20 \mathrm{~g}$, distilled water 1 liter) containing $2.4 \mathrm{mg} / \mathrm{ml}$ bromophenol blue as a $\mathrm{pH}$ indicator. The medium was inoculated by the isolates along with control (without inoculation) and incubated for 48 hours at $30{ }^{\circ} \mathrm{C}$ to observe a clear zone around the bacterial colony. Quantitative estimation of phosphate solubilization ( $\mathrm{Pi}$ ) was measured with the following formulae

Pi solubilization index $=$ Total diameter $($ colony + clear zone $) /$ Diameter of bacterial colony

\subsection{Indole-3- acetic acid (IAA) production}

Bacterial culture was inoculated into nutrient broth supplemented with $500 \mathrm{ppm}$ filter-sterilized tryptophan. A medium without 
tryptophan served as control. The growth was obtained for 48 hours at $30{ }^{\circ} \mathrm{C}$ at $150 \mathrm{rpm}$ and harvested by centrifugation at 6000 rpm for 10 minutes. For the $1 \mathrm{ml}$ supernatant, $4 \mathrm{ml}$ Salkowaski reagent was added and incubated at room at $35{ }^{\circ} \mathrm{C}$ for 20 minutes. The solution was observed for the development of pink color, and quantitative estimation was done at $535 \mathrm{~nm}$ against a blank using a standard curve (10-100 ppm) of known concentrations of IAA.

\subsection{Exopolysaccharide (EPS) production}

The isolates were also checked for EPS production quantitatively. A loop full of bacterial culture was inoculated in $25 \mathrm{ml}$ nutrient broth and incubated at $30{ }^{\circ} \mathrm{C}$ for 48 hours with a rotation of 150 $\mathrm{rpm}$. EPS extraction was carried out by following the method used (Mukherjee et al., 2019) with minor modifications. Bacterial cells were separated by centrifuging the growth at $10000 \mathrm{rpm}$ for 15 minutes at $4{ }^{\circ} \mathrm{C}$. The supernatant was precipitated by adding three volumes of pre-chilled acetone followed by incubation at $30{ }^{\circ} \mathrm{C}$ for 48 hours. EPS was collected by filtering the precipitate through Whatman filter paper. The filter paper was dried overnight at $58{ }^{\circ} \mathrm{C}$ and weighed. The number of EPS was determined by the weight difference of Whatman filter paper before and after filtration.

Based on the above experiments, one isolate was selected for pot trails, which can stand with salt and temperature stress and showed the highest level of above plant growth-promoting traits.

\subsection{In-vitro Pot Trails}

Genotobiotic pot experiments were designed in a plant growth chamber maintained at a temperature $30 \pm 2{ }^{\circ} \mathrm{C}$ with $70 \%$ relative humidity to estimate the plant growth-promoting potential of the isolate. Gramm seeds were surface sterilized by $70 \%$ ethyl alcohol wash 1 minute followed by rinsing with sterile distilled water and a 3 minutes wash with $0.1 \% \mathrm{HgCl}_{2}$. The seeds were rinsed with sterile distilled water again and incubated with the isolate's growth $\left(10^{7} \mathrm{CFU} / \mathrm{ml}\right)$ for 1 hour. Above treated seeds were sown at a depth of $5 \mathrm{~mm}$ of surface in pre-sterilized soil amended with $10 \%$ $\mathrm{NaF}$ concentration. Three seeds per pot $(10 \mathrm{~cm}$ in height and $5 \mathrm{~cm}$ in diameter) were maintained in six applications. Un-inoculated pot served as control. The growth of seedlings was recorded after 15 days by taking seed germination, root/shoot length, and no of lateral roots produced as plan growth parameter.

\subsubsection{Identification of bacterial isolate}

Genomic DNA was isolated by following the method used (Brigido et al., 2019). The microorganism was grown in $10 \mathrm{ml}$ of LB broth at $37{ }^{\circ} \mathrm{C}$ for 16 hours in a shaking incubator (200 rpm). The culture was centrifuged at $8,000 \mathrm{rpm}$ for 10 minutes. The bacterial pellet was dissolved in $15 \mathrm{ml}$ of $20 \mathrm{mM}$ Tris- $\mathrm{HCl}(\mathrm{pH}$ 8.0) buffer containing $10 \mathrm{mM} \mathrm{NaCl}, 1 \mathrm{mM}$ EDTA, $100 \mu \mathrm{g} / \mathrm{ml}$ proteinase $\mathrm{K}$, and $0.5 \%$ sodium dodecyl sulfate. This suspension was then incubated at $50{ }^{\circ} \mathrm{C}$ for 2 hours. Then an equal volume of phenol-chloroform-isoamyl alcohol $(25: 24: 1)$ was added to the suspension and centrifuged for 10 minutes at $8,000 \mathrm{rpm}$. The upper phase was removed and precipitated by adding 0.1 volume of $3 \mathrm{M}$ sodium acetate ( $\mathrm{pH}$ 5.2) and 2 volumes of $99 \%$ ethanol. The DNA precipitate was then collected by centrifugation at $8000 \mathrm{rpm}$ for 1 minute, washed with $70 \%$ ethanol, and dissolved in $3 \mathrm{ml}$ of TrisEDTA (10 mM Tris-HCl, 1 mM EDTA, pH 8.0) buffer. Polymerase Chain Reaction (PCR) was employed in a thermal cycler (BIORAD) to amplify $16 \mathrm{~S}$ rDNA of the isolate. The PCR reaction consists of $2.5 \mu \mathrm{l} 10 \mathrm{X}$ Taq DNA polymerase buffer, $1 \mu \mathrm{l}$ of $2.5 \mathrm{mM}$ dNTP mix, $1.5 \mu \mathrm{l}$ of $25 \mathrm{mM} \mathrm{MgCl}_{2}, 0.7 \mu \mathrm{l}$ of each 20 pmol forward and reverse primers, $0.2 \mu \mathrm{l}$ of $5 \mathrm{U}$ Taq DNA polymerase and $1 \mu \mathrm{l}$ of $100 \mathrm{ng}$ genomic DNA. The total volume was made $25 \mu \mathrm{l}$ with deionized water. The PCR was performed with a program encompassing initial denaturation at $95^{\circ} \mathrm{C}$ for 5 minutes, followed by 30 cycles of $95{ }^{\circ} \mathrm{C}$ for 30 seconds, $60^{\circ} \mathrm{C}$ for 30 seconds, $72{ }^{\circ} \mathrm{C}$ for 40 seconds, and a final extension at $72{ }^{\circ} \mathrm{C}$ for 7 minutes. The amplified product was electrophoresed in $1 \%$ agarose gel along with a known molecular weight marker. The desired fragment was excised from the gel and was purified and sequenced. The nucleotides sequence obtained was subjected to BLAST at NCBI to check for the homology of the sequence with the available sequences of the database. The Mega 5 software drew the phylogenetic tree to know the genetic relatedness of the isolate among the bacterial kingdom.

\subsection{Statistical Analysis}

Each experiment was conducted in triplicates, and values represent the mean \pm standard deviation. Data were analyzed by analysis of variance (ANOVA), and differences between experimental results were analyzed using Duncan's multiple range test (DMRT). $P<$ 0.05 was considered statistically significant.

\section{Results}

\subsection{Isolation of endophytic bacteria}

A total of six bacterial isolates were obtained from the root and nodules of the plant. No bacterial colony was seen from the surface wash. Among the isolated strains, four isolates were Gramnegative bacilli, while the remaining were Gram-positive rods. All these isolates were named as $1,2,3,4,5$, and 6 .

\subsubsection{Identification of Stress tolerant isolate}

The growth of isolate in nutrient broth supplemented with $\mathrm{NaF}$ at various concentrations shows diverse behavior. All isolates showed less growth as reported by earlier workers (Paul et al., 2014). Isolate 5 possesses the maximum capability to tolerate salt stress (Table1). It can grow well in nutrient broth supplemented with 10 g \% NaF compared to others. 
Table 1 Isolate tolerance towards the salt.

\begin{tabular}{|cc|}
\hline Isolate & CFU (colony forming units)/ml at $10 \mathrm{~g} \% \mathrm{NaF}$ concentration \\
\hline 1 & $100 \pm 10$ \\
\hline 2 & $50 \pm 06$ \\
\hline 3 & $200 \pm 15$ \\
\hline 4 & $250 \pm 15$ \\
\hline 5 & $1300 \pm 50$ \\
\hline 6 & $80 \pm 07$ \\
\hline
\end{tabular}

Here \pm represents the means of three replicates with $\mathrm{SD} \pm 10 \%$

Table 2 Plant growth promotional features by the Isolates at $30{ }^{\circ} \mathrm{C}$ without Salt stress

\begin{tabular}{|cccc|}
\hline Isolate & Phosphate solubilization Index $(\mathrm{Pi})$ & IAA production $(\mathrm{ppm})$ & EPS production $(\mathrm{g} / \mathrm{l})$ \\
\hline 1 & $1.1 \pm 0.1$ & Nil & $0.1 \pm 0.01$ \\
\hline 2 & $0.92 \pm 0.05$ & $41 \pm 3.1$ & $0.05 \pm 0.005$ \\
\hline 3 & Nil & Nil & $0.5 \pm 0.05$ \\
\hline 4 & $1.43 \pm 0.01$ & $81 \pm 6.5$ & $0.88 \pm 0.04$ \\
\hline 5 & $1.65 \pm 0.02$ & $72 \pm 5.5$ & $2.12 \pm 0.2$ \\
\hline 6 & Nil & $15 \pm 1.5$ & $0.03 \pm 0.002$ \\
\hline
\end{tabular}

Here \pm represents the means of three replicates with a SD $\pm 10 \%$

Table 3 Plant growth promotional features of isolate 5 at $30^{\circ} \mathrm{C}$ with salt concentration of $10 \%(\mathrm{~g})$
Isolate Phosphate solubilization Index $(\mathrm{Pi})$ IAA production (ppm)
EPS production $(\mathrm{g} / \mathrm{l})$

$5 \quad 1.2 \pm 0.2$

$48 \pm 0.12$

$3.24 \pm 0.3$

Here \pm represents the means of three replicates with $\mathrm{SD} \pm 10 \%$

Table 4 In-vivo plant growth promotion by the selected isolate

\begin{tabular}{|c|c|c|c|c|}
\hline & $\begin{array}{c}\text { Germination } \\
(\%)\end{array}$ & $\begin{array}{l}\text { Shoot length } \\
\text { (cms) }\end{array}$ & Root length (cms) & $\begin{array}{c}\text { Lateral roots } \\
\text { (numbers) }\end{array}$ \\
\hline Bacterial treatment & $75 \pm 1.1$ & $9.9 \pm 1.2$ & $2.3 \pm 0.3$ & $8 \pm 0.4$ \\
\hline $\begin{array}{c}\text { Control } \\
\text { (without bacterial treatment) }\end{array}$ & $52 \pm 0.7$ & $1.7 \pm 0.3$ & $0.5 \pm 0.1$ & $2 \pm 0.3$ \\
\hline
\end{tabular}

Here \pm represents the means of three replicates with a SD $\pm 10 \%$

\subsubsection{Screening of plant growth potential traits}

Isolates growth on Pikovskaya agar medium produces a clear zone around their colony, suggesting solubilization of phosphate present in the medium. The value for their Pi index was shown in Table 2, which indicates that isolate 5 solubilizes phosphate more comparatively.

The ability to convert tryptophan into indole acetic acid was determined qualitatively quantitatively for all isolates. The supernatant of Isolates 4 and 5 exhibited red color upon reaction with Salkowski's reagent (Table 2). IAA production was found maximum in isolate $4(81 \mathrm{ppm})$, while isolate 5 produced $72 \mathrm{ppm}$ from tryptophan. Table 2 suggests that EPS production was maximum when isolate 5 was grown $(2.12 \mathrm{~g} / \mathrm{l})$.

Isolate 5 was selected with its stress tolerance and plant growthpromoting features, among others. It is envisaged from Table 3 that the isolate holds the property of phosphate solubilization, IAA production, and EPS production. 


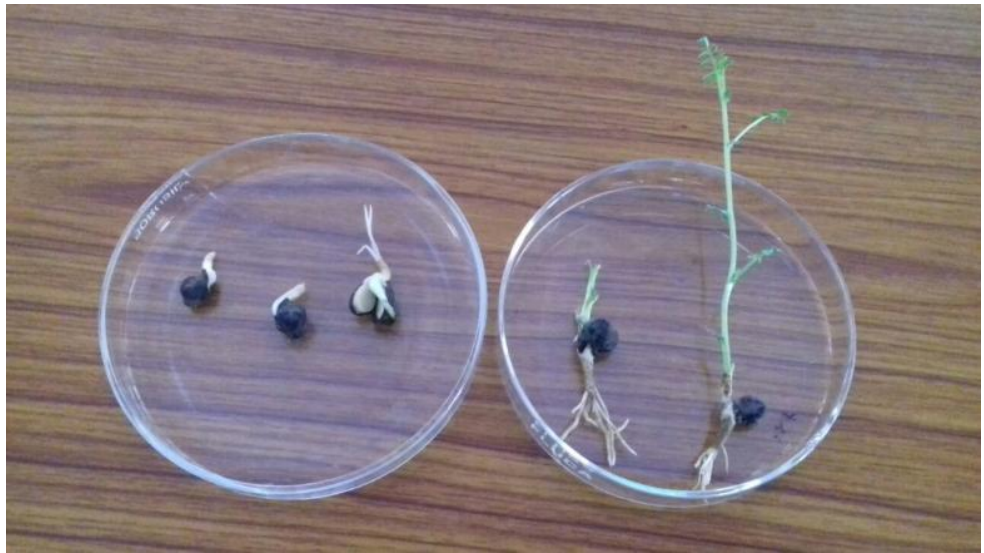

Figure 1 In-vivo plant growth potential of isolate

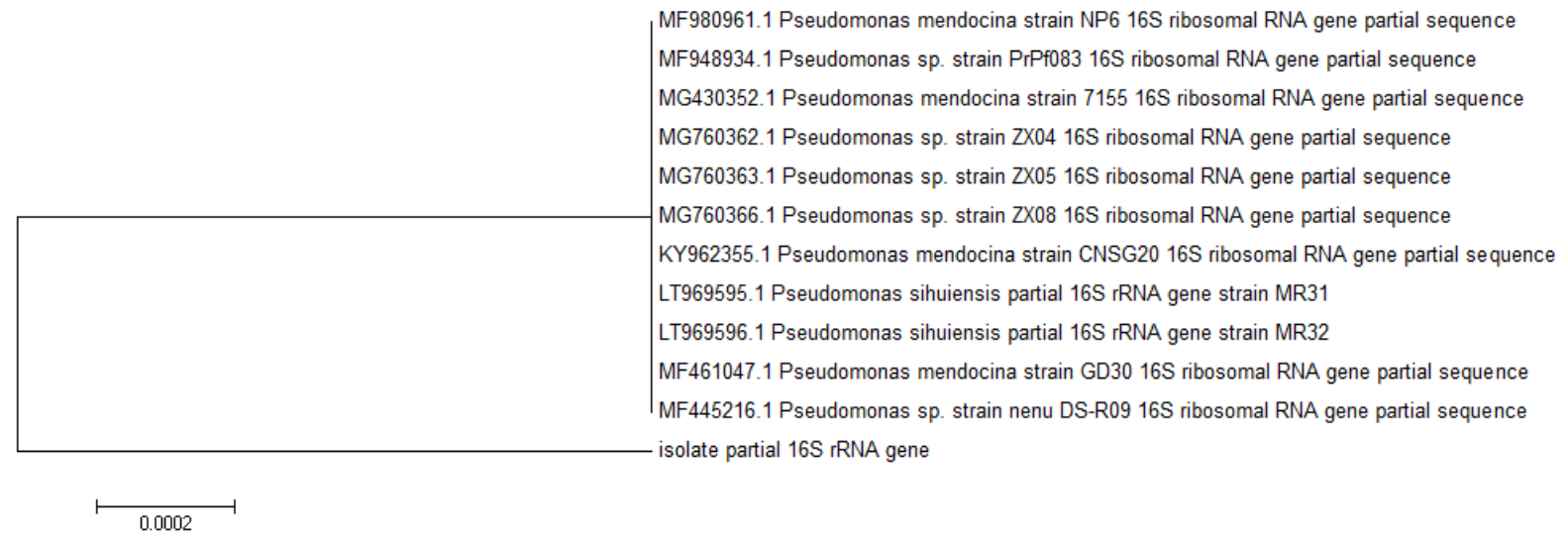

Figure 2 Phylogenetic analysis of partial 16S rDNA sequence of isolate along with related sequences at NCBI using Mega 5 with neighbour joining method.

\subsubsection{In- vivo plant growth potential}

Plant growth-promoting bacteria by various mechanisms including IAA production, EPS production, phosphate solubilization, and protect plants against various biotic and biotic stress conditions (IIangumaran \& Smith 2017). The seed treatment with the isolate increases the germination efficiency of seeds and positively affects the development of roots, lateral roots, and shoots (Table 4; Figure1).

\subsection{Identification of the isolate}

PCR amplification of the isolate was confirmed by agarose gel electrophoresis. 16S rDNA sequence obtained after sequencing showed 99\% similarity with Pseudomonas sihuiensis 16S rRNA gene strain MR 32 (LT969596.1) and P. mendocina16S rRNA gene strain GD 30. The related sequences were retrieved from NCBI and were used for phylogenetic analysis with MEGA 5 software using the neighbor joining method with a distance of 0.0002 (Figure 2).

\section{Discussion}

The isolate obtained in the current study were few. It may be because of plants used in the present study were taken from a semiarid zone where they face temperature, drought, and salinity stress. It has also been attributed to the study of Xu et al. (2018). They report delay and enrichment in sorghum root microbiome development because of the adverse effects of climatic conditions. Initially, these were differentiated based on morphological features. The poor growth of bacteria may be due to the effect of salt on the growth of rhizobacteria (Abdelmoumen et al., 1999). One of the isolates grows more comparatively in the presence of $\mathrm{NaF}$. The adaptation might be because of the production of ionophores in the cytosol of bacteria and others as suggested 
(Dutta et al., 2020), or the production salt regulated protective proteins in Pseudomoans (Paul \& Nair 2008).

Phosphate solubilization is considered one of the most critical traits of plant growth-promoting bacteria. It is well established that these bacteria release organic acids that chelate metal ions bonded to phosphate and make phosphorus free for plant growth. Various strains of Pseudomonas are widely documented for phosphate solubilization (Kohler et al., 2006; Ramachandran et al., 2007; Srinivasan et al., 2012; Otenio et al., 2015; Paul \& Sinha, 2017)

Indole acetic acid and its analog are plant auxins and responsible for shoot elongation. Bacteria employ this molecule as a part of its root colonization process, phyto-stimulation, circumvention of plant defense mechanism, and signaling. IAA production is quite common in endophytes (Singh \& Gaur 2016). Bacteria produce exopolysaccharides (EPS) as a protective strategy to mitigate drought and salinity stress. These molecules interact with soil particles and make a microenvironment that increases water retention by soil particles. In addition to the above, they are thought to maintain high water potential around the plant roots and improve the permeability of soil nutrients towards plants (Sandhya \& Ali 2015; Vurukonda et al., 2016 \& Liu et al., 2017) also recognized the importance of EPS formation by plant growthpromoting bacteria to overcome the effects of salt stress in plants. Isolate 5 was further selected to check in vivo plant growth potential as it possesses the ability to grow in the presence of salt, as suggested (Egamberdieva et al., 2011). However, a decrease in phosphate solubilization and IAA production was noticed in the presence of salt. (Lebrazi et al. 2020) also reported a reduction in phosphate solubilization in the presence of salt in Pseudomomas. A marked increase in EPS production was observed, which is attributed to the fact that salinity induces bacteria to produce more EPS as a safeguard in challenging environments. In-vivo study revealed that the isolate possesses the potential to increase plant growth in pot trails also. (Mansotra et al. 2015) bioaugumented the rhizosphere of chickpea to increase its productivity by Mesorhizobium, Pseudomonas, and Piriformospora. The study conducted by (Zaheer et al. 2016 \& Sathya et al. 2016) also recommended the using of plant growth-promoting bacteria to increase the productivity of crops. Thus the study finds Pseudomonas a good biofertilizer among the significant plant growth-promoting endophytes as identified by earlier workers from diverse locations (Jasim et al., 2014; Tashi-Oshnoei et al., 2017 \& Hassan, 2017).

\section{Conclusion}

Crop plants are facing numerous challenges nowadays in terms of both biotic and abiotic stress. Besides the inherent capability of the plant to survive in adverse conditions, endophytic bacteria also help them to complete their life cycle successfully. In the present study, an endophyte bacterium was isolated and identified as Pseudomonas. The bacteria possess the potential to promote plant growth with $10 \% \mathrm{NaF}$ concentration. Hence, it can be a promising bio-fertilizer to overcome the adverse effects of salinity in an ecofriendly manner.

\section{Conflict of Interest}

All the authors have approved the manuscript and agree with submission to your esteemed journal. There are no conflicts of interest to declare.

\section{References}

AbdAllah EA, Alqarawi AA, Hashem A, Radhakrishnan R, AlHuqail AA, Al-Otibi (2017) Endophytic bacterium Bacillus subtilis (BERA 71) improves salt tolerance in chickpea plants by regulating the plant defense mechanisms. Journal of Plant Interactions 13:37-44.

Abdelmoumen H, Filali-Maltouf A, Neyra M, Belabed A, El Idrissi MM (1999) Effect of high salts concentrations on the growth of rhizobia and responses to added osmotica. Journal of Applied Microbiology 86(6):889-898.

Ahmad P, Hashem A, AbdAllah E F, Alqarawi AA, John R, Egamberdieva D (2015) Role of Trichoderma harzianum in mitigating $\mathrm{NaCl}$ stress in Indian mustard (Brassica juncea $\mathrm{L}$ ) through antioxidative defense system. Frontiers of Plant Sciences 6:868.

Brigido C, Singh S, Menendez E, Tavares MJ, Glick BR, Felix MDR, Oliveira S, Carvalho M (2019) Diversity and Functionality of Culturable Endophytic Bacterial Communities in Chickpea Plants. Plants (Basel) 8(2):42.

De Vuyst L, Vanderveken F, Van de Ven S, Degeest B (1998) Production and isolation of exopolysaccharides from Streptococcus thermophilus grown in a milk medium and evidence for their growth-associated biosynthesis. Journal of Applied Microbiology 84:1059-1068.

Dutta M, Pan B, Ghosh K (2020) Isolation of Fluoride Tolerant Bacillus spp (KT201599, KT201600) from the Midgut of Drosophila melanogaster: Their Probable Role in Fluoride Removal. Proceedings of Zoological Society 73, 175-183.

El-Akhdar I, Elsakhawy T, Abo-Koura HA (2020) Alleviation of Salt Stress on Wheat (Triticum aestivum L.) by Plant Growth Promoting Bacteria strains Bacillus halotolerans MSR-H4 and Lelliottia amnigena MSR-M49. Journal of Advances in Microbiology 20(1): 44-58. 
Egamberdieva D, Kucharova Z, Davranov K, Berg G, Makarova N, Azarova T (2011) Bacteria able to control foot and root rot and to promote growth of cucumber in salinated soils. Biological Fertilizers and Soils 47:197-205.

Egamberdieva D, Wirth SJ, Shurigin VV, Hashem A, AbdAllah EF (2017) Endophytic bacteria improve plant growth, symbiotic performance of chickpea (Cicer arietinum L.) and induce suppression of root rot caused by Fusarium solani under Salt Stress. Frontiers of Microbiology 8:1887.

Flowers TJ, Gaur PM, Gowda CL, Krishnamurthy L, Samineni S, Siddique KH (2010) Salt sensitivity in chickpea. Plant Cell Environment 33:490-509.

Ghaffari MR, Ghabooli M, Khatabi B, Hajirezaei MR, Schweizer P, Salekdeh GH (2016) Metabolic and transcriptional response of central metabolism affected by root endophytic fungus Piriformospora indica under salinity in barley. Plant Molecular Biology 90:699-717.

Hashem A, AbdAllah EF, Alqarawi A, Al-Huqail AA, Wirth S, Egamberdieva D (2016) The interaction between arbuscularmycorrhizal fungi and endophytic bacteria enhances plant growth of Acacia gerrardii under salt stress. Frontiers of Plant Sciences 7:1089.

Hassan SE (2017) Plant growth-promoting activities for bacterial and fungal endophytes isolated from medicinal plant of Teucrium polium L. Journal of Advance Research 8:687-695.

Ilangumaran G, Smith DL (2017) Plant growth promoting rhizobacteria in amelioration of salinity stress: a systems biology perspective. Frontiers of Plant Sciences 8:1768.

Jasim B, Joseph AA, John CJ, Mathew J, Radhakrishnan EK (2014) Isolation and characterization of plant growth promoting endophytic bacteria from the rhizome of Zingiber officinale. 3 Biotech 4:197-204.

Khan HA, Siddique KHM, Colmer TD (2017) Vegetative and reproductive growth of salt-stressed chickpea are carbon-limited: sucrose infusion at the reproductive stage improves salt tolerance. Journal of Experimental Botany 68: 2001-2011.

Kohler J, Caravaca F, Carrasco L, Roldan A (2006) Contribution of Pseudomonas mendocina and Glomus intraradices to aggregate stabilization and promotion of biological fertility in rhizosphere soil of lettuce plants under field conditions. Soil Use Management 22: 298-304.

Lebrazi S, Niehaus K, Bednarz H (2020) Screening and optimization of indole-3-acetic acid production and phosphate solubilization by rhizobacterial strains isolated from Acacia cyanophylla root nodules and their effects on its plant growth. Journal of Genetic Engineering Biotechnology 18: 71.

Li L, Wang X, Zhu P, Wu H, Qi S (2017) Plant growth-promoting endophyte Piriformospora indica alleviates salinity stress in Medicago truncatula. Plant Physiology and Biochemistry 119:211-223.

Liu J, Chi X, Huimin W, Shuang P, Liu J, Changai K (2017) Recent advances in endophyticexo polysaccharides: Production, structural characterization, physiological role and biological activity. Carbohydrate Polymers 157: 1113-1124.

Mansotra P, Sharma P, Sharma S (2015) Bioaugmentation of Mesorhizobium cicer, Pseudomonas spp. and Piriformospora indica for sustainable chickpea production. Physiology and Molecular Biology of Plants 21:385-393.

Mukherjee P, Mitra A, Roy M (2019) Halomonas Rhizobacteria of Avicennia marina of Indian Sundarbans Promote Rice Growth Under Saline and Heavy Metal Stresses Through Exopolysaccharide Production. Frontiers of Microbiology 10:1207.

Oteino N, Lally RD, Kiwanuka S, Lloyd A, Ryan D, Germaine KJ (2015) Plant growth promotion induced by phosphate solubilizing endophytic Pseudomonas isolates. Frontiers of Microbiology 6: 745 .

Paul D, Nair S (2008) Stress adaptations in a plant growth promoting Rhizobacterium (PGPR) with increasing salinity in the coastal agricultural soils. Journal of Basic Microbiology 48:1-7.

Paul D, Sinha SN (2017) Isolation and characterization of phosphate solubilizing bacterium Pseudomonas aeruginosa KUPSB12 with antibacterial potential from river Ganga, India. Annals of Agriculture Sciences 15:130-136.

Paul S, Aggarwal C, Thakur JK, Rathi MS (2014) Effect of salt on growth and plant growth promoting activities of Azotobacter chroococcum isolated from saline soils. Environmental Ecology $32: 1255-1259$.

Ramachandran K, Srinivasan V, Hamza S, Anandaraj M (2007) Phosphate solubilizing bacteria isolated from the rhizosphere soil and its growth promotion on black pepper Piper nigrum L. cuttings. In: Velazquez E, Rodriguez-Barrueco C (Eds) First International Meeting on Microbial Phosphate Solubilization. Developments in Plant and Soil Sciences, vol 102.Springer.

Sabagh AE, Hossain A, Barutçular C, Islam MS, Ratnasekera D, Kumar N, Meena RS, Gharib HS, Saneoka H, Da Silva J (2019) Drought and salinity stress management for higher and sustainable 
canola (Brassica napus L.) production: A critical review. Australian Journal of Crop Sciences 13(1):88.

Sandhya V, SAli (2015) The production of exopolysaccharide by Pseudomonas putidagapp 45 under various abiotic stress conditions and its role in soil aggregation. Microbiology 84:512519 .

Santoyo G, Moreno-Hagelsieb G, Orozco-Mosqueda MD, Glick BR (2016) Plant growth-promoting bacterial endophytes. Microbiological Research 183:92-99.

Sathya A, Vijayabharathi R, Srinivas V, Gopalakrishnan S (2016) Plant growth-promoting actinobacteria on chickpea seed mineral density: an upcoming complementary tool for sustainable biofortification strategy. 3 Biotech 6:1-6.

Schirawski J, Perlin MH (2018) Plant- microbe interaction the good, the bad and the diverse. International Journal of Molecular Sciences 19:1374.

Singh SP, Gaur R (2016) Evaluation of antagonistic and plant growth promoting activities of chitinolytic endophytic actinomycetes associated with medicinal plants against Sclerotium rolfsii in chickpea. Journal of Applied Microbiology 121:506-518.

Srinivasan R, Yandigeri MS, Kahsyap S, Alagawadi AR (2012)
Effect of salt on survival and P-solubilization potential of phosphate solubilizing microorganisms from salt affected soils. Saudi Journal of Biological Sciences 19:427-434.

TashiOshnoei F, Harighi B, Abdollahzadeh J (2017) Isolation and identification of endophytic bacteria with plant growth promoting and biocontrol potential from oak trees. Forest pathology 47:12360

Vurukonda SSK, Vardharajula S, Shrivastava AS (2016) Enhancement of drought stress tolerance in crops by plant growth promoting rhizobacteria. Microbiological Research 184:13-24.

Xu L, Naylor D, Dong Z, Simmons T, Peirroz G, Hixson KK (2018) Drought delays development of the sorghum root microbiome and enriches for monoderm bacteria. Proceedings of the National Academy of Sciences of the United States of America 115:4284-4293.

Zaheer A, Mirza BS, Mclean JE, Yasmin S, Shah TM, Malik KA, Mirza MS (2016) Association of plant growthpromoting Serratia spp. with the root nodules of chickpea. Research Journal of Microbiology 167:510-520.

Zhang S, Gan Y, Xu B (2019) Mechanisms of the IAA and ACCdeaminase producing strain of Trichoderma longibrachiatum $\mathrm{T} 6$ in enhancing wheat seedling tolerance to $\mathrm{NaCl}$ stress. BMC Plant Biology 19:22. 